Maria Radziszewska

Katedra Dydaktyki i Historii Wychowania

Uniwersytet Warmińsko-Mazurski w Olsztynie

\title{
Życie codzienne nauczycieli szkół powszechnych w Okręgu Mazurskim w świetle wspomnień i pamiętników (część II)
}

\begin{abstract}
Maria Radziszewska, Public School Teachers' Daily Lives in the District of Masuria in the Light of Memories and Diaries

The article concerns the problem of public school teachers' daily lives in Masuria. The analysis took into account such components of everyday life as: travel to Warmia and Masuria, reasons for choosing the profession, education, work areas, the conditions and working methods, types of nourishment at school, the financial conditions of schools and some elements of private life. The issue of teachers' daily lives deserves special attention because of the specific situation of Polish education in Warmia and Masuria in the school years 1944/1945-1945/1946. Teachers were mainly engaged in organizing Polish schools from the start in order to promote the Polish language among youth and children from different nationalities and cultures. Their daily lives were strongly influenced by determining the final borders of the District of Masuria, the action for preserving this land, the constant risk and problems with the staff, rooms and money. The article is not only about daily professional life (part I) but also about teachers' personal lives (part II). The sphere of private life refers to issues such as food supplies, households, salaries, housing, family matters, forms of spending leisure time. There is certainly a need for broader studies using a variety of source materials. The sources of an autobiographical nature, memories and diaries, have been mainly used to present the issue.
\end{abstract}

Keywords: Education in Warmia and Masuria, Teachers in Poland $20^{\text {th }}$ Century

Niniejsze opracowanie jest kontynuacją - podjętej przez autorkę - problematyki życia codziennego nauczycieli szkół powszechnych w Okręgu Mazurskim. Ze względów edytorskich zostało ono podzielone na dwie części. W poprzednim numerze „Biuletynu Historii Wychowania” w części pierwszej zamieszczone zostały materiały dotyczące życia codziennego nauczycieli w pracy zawodowej. Szczególnie omówiono takie składniki codzienności, jak: podróż na Warmię i Mazury, motywy wyboru zawodu, drogi edukacji, obszary pracy, przejawy konsumpcji w szkole, warunki i metody pracy. W części drugiej 
przedstawione zostaną warunki materialne szkół powszechnych oraz obraz życia prywatnego nauczycieli.

$$
* * *
$$

Zorganizowanie systematycznej nauki w szkolnictwie powszechnym w Okręgu Mazurskim miało zaowocować upowszechnianiem języka polskiego i integracją społeczności szkolnej. Niestety ze względu na warunki materialne szkół, a także potrzeby kadrowe nauka w niejednej szkole była nieregularna, co z kolei nie przynosiło dobrych efektów w wyrównywaniu szans edukacyjnych dzieci na poziomie kulturalno-społecznym. W szkole w Reszkach w powiecie ostródzkim początkowo: Lekcje odbywaty się mniej więcej dwa razy w tygodniu bez uprzedzenia. Dzieci zwoływano dopiero wówczas, kiedy nauczycielki przyjechaty do wsi. Systematyczna nauka rozpoczęła się od czasu, kiedy przyjechałam na stałe do Reszek. Warunki pracy byty bardzo ciężkie. [...] Dodatkowa trudnościa było to, że dzieci uczęszczające do jednej klasy były w różnym wieku i mówity $w$ kilku językach - mazurskim /mieszany z niemieckim /rosyjskim, białoruskim i polskim. Trzeba było pracować z nimi indywidualnie, nawet poza godzinami lekcyjnymi. $\mathrm{Na}$ szczęście, byty to dzieci wyjątkowo zdyscyplinowane, spragnione nauki, biorace żywy udziat w lekcji. [...] Stopniowo praca w szkole uktadała się coraz lepiej. Dzieci miały zeszyty, a potem i podręczniki szkolne ${ }^{1}$.

Składnikiem codzienności w pracy zawodowej nauczycieli jest także kwestia materialna szkół, która zwraca uwagę czytelnika na problemy, z jakimi w tym czasie borykali się nauczyciele. Oprócz podręczników, książek, brakowało prawie wszystkiego, poczynając od wyposażenia budynku szkolnego, a na pomocach naukowych kończąc. Wobec tak poważnych braków należy postawić pytanie: Jak w takich okolicznościach radzili sobie nauczyciele?

Dzięki wspomnieniom i pamiętnikom mamy wgląd w to, co nauczyciele szkół powszechnych w odniesieniu do zjawiska życia codziennego musieli robić sami i jak to wykonywali. Wobec braku jakichkolwiek pomocy naukowych nauczyciele sami tworzyli niezbędne pomoce dydaktyczne. Na przykład nauczycielka ze szkoły w Suszu, ucząc dzieci alfabetu, potrzebowała zobrazować poszczególne literki, wobec tego opisuje jak przygotowywała niezbędne pomoce: [...] rysując do każdego wyrazu obrazki poczatkowo ołówkiem, później barwne, wzorowane na nowo wydanym nakładzie egzemplarza [...] i inne pomoce naukowe jak ruchomy alfabet, loteryjki trzeba było sporzadzać samej. Ta praca absorbowata wiele czasu, który dopiero byt wykorzystywany wieczorem na te $r z e c z y^{2}$. Inna nauczycielka ze szkoły w Dźwierzutach relacjonuje, jak dzięki uprzejmości wójta gminy i sekretarza mogła zatroszczyć się o przykłady słowa pisanego: Pozwolili mi korzystać z maszyny do pisania, na której odbijałam teksty do czytania dla dzieci, począt-

${ }^{1}$ AZG ZNP, zespół: Biuro Historii, sygn. 899, Kosowa Nadzieja. Moje wspomnienia. Praca zgłoszone przez Tadeusza Petera w 1979 roku na konkurs historyczny zorganizowany przez ZG ZNP z okazji Jubileuszu 50-lecia powstania szkół polskich na Warmii i Mazurach, k. 1.

2 OBN, zespół: Zbiory Specjalne, sygn. R - 306. Józefa Zamielska. Pamiętnik nauczycielki szkoły podstawowej w Suszu, k. 2. 
kowo redagując treść, a później posługiwałam się przedwojennym podręcznikiem³. Szczególne trudności w pozyskaniu specjalistycznych pomocy naukowych trapiły nauczycieli przedmiotów ścisłych. Jednak i oni poszukiwali sposobów ich rozwiązania, co ilustruje poniższa relacja: Ja, jako nauczycielka fizyki i chemii, wyszukiwałam pomoce naukowe na śmietnikach. Były to druty, blaszki, probówki, z których następnie na lekcjach z chętnymi uczniami sporzadzałam najprostsze pomoce naukowe ${ }^{4}$.

W rytm ówczesnej codziennej pracy w szkole należy wpisać nieustanne poszukiwanie jakichkolwiek książek w języku polskim, papieru i przyrządów do pisania. Pierwszy nominowany nauczyciel Okręgu Mazurskiego tak przedstawia dzień powszedni w szkole: Na początku dzieci pisały na tablicach tupkowych, któreśmy znaleźli rozsypane na nasypie kolejowym w poblizu wioski [...] »Mały Płomyczek«'38 roku, którego otrzymatem od pewnego polskiego lotnika, stuży mi aż do otrzymania elementarzy i podręczników do przygotowania dzieci $w$ czytaniu $i$ deklamowaniu wierszy itd. ${ }^{5}$ Inni nauczyciele do nauki czytania wykorzystywali książki i czasopisma przedwojenne ${ }^{6}$, jak np. Mały Polak w Niemczech ${ }^{7}$, książeczki do nabożeństwa, śpiewniki kościelne ${ }^{8}$ oraz: cytaty z kalendarzy $i$ innych książek uratowanych przed okiem hitlerowców i przed zniszczeniem przez myszy ${ }^{9}$. W codziennej pracy szkolnej nauczyciele autochtoni posługiwali się podręcznikiem niemieckim zaś nauczyciele przesiedleńcy - podręcznikiem w języku rosyjskim, co egzemplifikuje wspomnienie nauczycielki z Ostródy: Jedynym podręcznikiem $w$ szkole byly zbiory zadań matematycznych $w$ języku rosyjskim, które przywiozłam ze soba i z którego teraz tlumaczyłam zadania z matematyki ${ }^{10}$.

Kreatywność nauczycieli podpowiadała im różne rozwiązania w sytuacji braków nawet czystego papieru do pisania. Dlatego też zarówno uczniowie (Zeszyty 16-kartkowe z przydziału UNRRY nie wystarczały. Dzieci pisały na makulaturze niemieckiej. Książek brakowało. Mieliśmy kilka podręczników przedwojennych i kilka z wydania moskiewskiego (dla szkót polskich ZSRR). Klasa pierwsza utrwalała wiadomości na gazetach i czasopismach ${ }^{11}$ ), jak i nauczyciele korzystali z makulatury niemieckiej, co ilustruje wspomnienie ze Szkoły Powszechnej nr 1 w Kętrzynie: Pierwsze dzienniki też były zrobione

${ }^{3}$ OBN, zespół: Zbiory Specjalne, sygn. R - 158/X/1, Wspomnienia nauczycieli, wyciagi z kronik szkolnych, odpisy protokołów powizytacyjnych $i$ wycinki z prasy (lata 1945-1969). Zbiory Stanisława Witkowskiego, k. 190.

${ }^{4}$ Zbiory archiwalne Szkoły Podstawowej nr 1 im. Ryszarda Knosały w Olsztynie. Kronika Szkoły, Ze wspomnień nauczycielki Marii Rajewskiej.

${ }^{5}$ OBN, zespół: Zbiory Specjalne, sygn. R - 158/X/1, Wspomnienia..., k. 123-124.

${ }^{6}$ Archiwum Państwowe w Olsztynie (APO), zespół: Kuratorium Okręgu Szkolnego w Olsztynie (KOS), sygn. 495/17, Sprawozdanie ze stanu szkolnictwa powszechnego Okręgu Szkolnego Mazurskiego według stanu z dnia 1 marca 1946 r., k 23.

${ }^{7}$ OBN, zespół: Zbiory Specjalne, sygn. R - 465, Paweł Turowski, Sto siedemdziesiąt lat walki o mowę ojczysta jednej wsi warmińskiej Tomaszkowo /1966/, k 92.

${ }^{8}$ OBN, zespół: Zbiory Specjalne, sygn. R - 158/X/1, Wspomnienia ..., k 126.

9 OBN, zespół: Zbiory Specjalne, sygn. R - 465, Paweł Turowski..., k 92.

${ }^{10}$ AZG ZNP, zespół: Biuro Historii, sygn. 899, Kosowa Nadzieja..., k 1.

${ }^{11}$ OBN, zespół: Zbiory Specjalne, sygn. R - 158/X/1, Wspomnienia ..., k. 69. 
przez nas ze starych poniemieckich druków $w^{12}$. W innej szkole: pisano na szarym papierze pakowym, na kwitach kasowych, na marginesach niemieckich ksiażek. Nie było nawet kredy do pisania na tablicy, ale szybko chłopcy znaleźli na to radę. Otóż niemal w każdym mieszkaniu byty gipsowe figurki Hitlera. Któryś z chłopców chwycił kawałek takiej figurki znaleziony w spalonym domu i począ nim rysować na drzwiach. Świetnie pisało. Od tego czasu $w$ razie potrzeby rzucano Hitlerem $w$ ogień $i$ po wypaleniu stawat sie $k r e d a^{13}$. Warto podkreślić, że jeszcze w marcu 1946 r., we wszystkich powiatach w Olsztyńskiem odczuwało się zupełny brak pomocy naukowych, a znikome resztki zniszczone i potłuczone nie przedstawiały żadnej wartości pomocniczej w nauce ${ }^{14}$.

Istotną kwestią życia codziennego nauczycieli była organizacja zajęć dydaktycznych. Z braków kadrowych niektórzy nauczyciele uczyli w więcej niż jednej szkole. Fakt ten potwierdza nauczyciel Antoni Kozłowski: Uczyłem w Rusku, ale w Sapłacie odległym o cztery km była wyposażona szkoła. Pojechałem po kilka ławek i tablicę. Sołtys z miejscową ludnościa wymusili na mnie zgodę na nauczanie ich dzieci i wtedy wypożyczyli kilka ławek i tablice. Uczyłem wtedy w Rusku od godziny 8.00-12.00, a od 12.30 - 16.30 w Sapłacie ${ }^{15}$. Również program zajęć lekcyjnych nie był bardzo rozbudowany, zwłaszcza w przeważających w Okręgu Mazurskim szkołach jednoklasowych (zob. załącznik, s. 150). W zależności od kwalifikacji nauczyciela i poziomu wiedzy uczniów początkowo program nauczania ograniczał się do lekcji języka polskiego. W szkole w Stębarku w powiecie ostródzkim nauczycielka posiadająca dwie klasy szkoły średniej uczyła dzieci: tylko języka polskiego, matematyki i geografii ${ }^{16}$.

Ogromny wpływ na życie codzienne nauczycieli, a także uczniów miało częste przerywanie lekcji, którego powodem były: donosy o szabrowaniu i rabunku, jak też wielokrotne alarmy $w$ akcji wyłapywania umundurowanych lub cywilnych opryszków przez czynniki wojskowo-policyjne ${ }^{17}$. Na inne zakłócenia procesu dydaktycznego wskazuje poniższy fragment: „dn. 23. X. 1945 r. [...] budynek szkolny zajmowali jeszcze sowieccy żołnierze i sowieccy robotnicy rolnicy, którzy byli sprowadzeni do kopania kartofli. Warunki higieniczne okropne. Nieład, brud wszędzie. Lokatorzy ciągle pijani. Częsta strzelanina na korytarzu. Nawet w czasie wizytacji były strzały na korytarzu. Kierownik nie miał dostępu do kuchni. Do szkoły i prywatnego mieszkania nauczyciela ob. Konieckiego wprowadził żołnierzy wójt gm. Wernegitten. W tych warunkach prowadzono naukę. Były czynne: kl. I-II-III-IV i V o łącznej liczbie 47 dzieci. Na twarzach kierownika

12 Ibidem, k. 83.

13 Zbiory archiwalne Szkoły Podstawowej nr 1 im. Ryszarda Knosały w Olsztynie. Kronika Szkoły, Ze wspomnień kierownika szkoty Leona Bowszysa.

14 APO, zespół: KOS, sygn. 495/17, Sprawozdanie ze stanu szkolnictwa powszechnego Okręgu Szkolnego Mazurskiego według stanu z dnia 1 marca 1946 r., k. 21.

15 AZG ZNP, zespół: Biuro Historii, sygn.1023, Organizacja szkolnictwa na Warmii i Mazurach w latach 1945-1950, k.28-39. Opracowanie Tadeusza Petera zgłoszone w 1979 roku na konkurs historyczny pt. „Jubileusz 50-lecia szkół polskich na Warmii i Mazurach” zorganizowany przez ZG ZNP, k. 30-31.

${ }^{16}$ AZG ZNP, zespół: Biuro Historii, sygn. 899, Szkoła Stębark, bez pag. Praca zgłoszone przez Tadeusza Petera w 1979 roku na konkurs historyczny zorganizowany przez ZG ZNP z okazji Jubileuszu 50-lecia powstania szkół polskich na Warmii i Mazurach.

${ }^{17}$ OBN, zespół: Zbiory Specjalne, sygn. R - 465, Paweł Turowski..., k. 93. 
i nauczycieli widać było wyczerpanie fizyczne i nerwowe"18. Takie sytuacje potęgowały niepokój oraz strach i w tej powojennej rzeczywistości były stałym elementem codzienności wszystkich mieszkańców Okręgu Mazurskiego.

Wybrane źródła narracyjne pozwalają też stwierdzić, czym zajmowali się nauczyciele po zakończeniu zajęć lekcyjnych. Dowiadujemy się z nich, jak ważną kwestię w szkolnej codzienności stanowiła działalność społeczna. O różnych formach aktywności nauczycieli traktują poniższe relacje: Nastepna moja czynnościa było zorganizowanie koła samoobrony [...] kuchni stałej [...] walki z groźnymi chorobami tyfusem, świerzbem, chorobami wenerycznymi itd. Wiosna 1946 roku zorganizowatem koło gminne PCK z siedziba w Pluskach ${ }^{19}$. Inni nauczyciele w Okręgu Mazurskim podkreślają, jak: Mimo trudnych warunków bytowych ochoczo pracowaliśmy zawodowo i spotecznie. Wspólnymi siłami organizowaliśmy różne okolicznościowe uroczystości, jak „Święto Morza” i obchód 535-tej rocznicy bitwy pod Grunwaldem ${ }^{20}$. Przy obchodach bitwy pod Grunwaldem warto zatrzymać się dłużej, gdyż była to pierwsza uroczysta rocznica na polach bitwy w wolnej Polsce. To niecodzienne święto odbywało się też przy zaangażowaniu i udziale nauczycieli: W sam dzień uroczystości jechaliśmy ze sztandarami na dwóch ciężarówkach na miejsce chwały polskiego oręza. Przed trybuna honorowa ustawiono szeregi dzieci naszej szkoły i około 70 uczni szkoły olsztyńskiej [...] formacje wojska polskiego $i$ oddziały wojsk radzieckich [...] grupy organizacji młodzieżowych oraz masa ludności. Gdy po dźwiękach hymnu narodowego Prezydent Krajowej Rady Narodowej Bolesław Bierut w otoczeniu członków Rządu Polskiego i generatów kroczył na miejsce honorowe, wystapiła uczennica naszej szkoty [...] i krótkim wierszykiem przywitała Prezydenta w imieniu wszystkich dzieci warmińsko-mazurskich, wręczając mu przy tym wiąkę białoczerwonych róż ${ }^{21}$. To niecodzienne wydarzenie w tej powojennej rzeczywistości nabierało głębszego znaczenia w świadomości rodzimych, jak i nowych mieszkańców wyzwolonej Warmii i Mazur. Dla nich to w ramach oświaty dorosłych nauczyciele angażowali się w prowadzenie kursów dokształcających i repolonizacyjnych. Praca na kursach repolonizacyjnych przeznaczonych dla autochtonów - zdaniem nauczycielki z Ostródy - dawała mi wiele satysfakcji, ponieważ zblizała mnie bardziej do środowiska, pozwalała na lepsze poznanie rodziców moich uczniów i dawała bardzo widoczne efekty. Bliski kontakt ze środowiskiem pomógł mi wiele lat później w prowadzeniu Uniwersytetu Powszechnego dla Rodziców ${ }^{22}$.

\footnotetext{
${ }^{18}$ APO, zespół: KOS, sygn. 495/30, Sprawozdanie z wizytacji publicznej szkoły powszechnej w Wernegitten, gm. Wernegitten z dnia 13 marca 1946 r., k. 184.

${ }_{19}$ OBN, zespół: Zbiory Specjalne, sygn. R - 323, Czesław Boguski, Moje wspomnienia, k. 5-7.

${ }^{20}$ OBN, zespół: Zbiory Specjalne, sygn. R - 10, Augustyn Klimek, Stary Wiarus [wspomnienia z lat 1892-1961], k. 10.

${ }^{21}$ OBN, zespół: Zbiory Specjalne, sygn. R - 465, Paweł Turowski..., k. 94.

${ }^{22}$ AZG ZNP, zespół: Biuro Historii, sygn. 899, Kosowa Nadzieja..., k. 4.
} 


\section{Obraz życia prywatnego nauczycieli}

Równolegle z pracą w szkole toczyło się życie osobiste nauczycieli. Codzienność, jakiej doświadczali nauczyciele, ich życiowe dole i niedole sprowadzały się najczęściej do zaspokojenia podstawowych potrzeb ludzkiej egzystencji (warunki socjalno-bytowe).

Dzięki pamiętnikom mamy wgląd w to, jak ówcześnie nauczycieli rodzili sobie $\mathrm{z}$ aprowizacją i co konsumowali, w jakich mieszkali warunkach, co robili w wolnych chwilach?

Pierwsi nauczyciele szkół powszechnych zapatrywali się w żywność u radzieckiego komendanta, u gospodarza bądź własnymi ścieżkami poszukiwali żywności, jak np. nauczyciel A. Wesołek z powiatu olsztyńskiego: Nauczyciel na początku bez wypłaty pensji musiat iść na żebry i prosić o chleb. Często na próżno ${ }^{23}$. Wobec braku placówek handlowych zaczęto organizować stołówki przyzakładowe i wydawać bezpłatne obiady oraz przydziały chleba, tłuszczu, marmolady, cukru, kawy, zapałek i czasami mięsa ${ }^{24}$. Osoby uprawnione, w tym i nauczyciele mogli korzystać z tych przywilejów. A. Klimek, inspektor szkolny w Biskupcu tak komentuje sytuację aprowizacyjną w połowie 1945 r.: W starostwie zgłosiłem się do wicewojewody [...] który wyrazil swe zadowolenie z przybycia organizatora szkolnictwa polskiego na terenie powiatu, polecił burmistrzowi miasta przydzielić mi pokój mieszkalny i wciagnać na listę uprawnionych do korzystania ze stotówki. $Z$ wyżywieniem było bardzo trudno. Sklepów z artykułami spożywczymi nie było. W stołówce byt jednostajny jadtospis, mianowicie: na śniadanie i kolacje -czarna kawa i chleb razowy - na obiad - kasza lub kasza z ziemniakami ${ }^{25}$. Również w Olsztynie jadłospis na stołówce nauczycielskiej nie był bardziej urozmaicony: Obiad tam składał się z talerza zupy (bez drugiego dania) i kawałka (gliniastego) chleba ${ }^{26}$. Dużą pomoc żywieniową przynosiły nauczycielom i uczniom stołówki szkolne. Jednak te zaczęły powstawać dopiero w ostatnim kwartale $1945 \mathrm{r}$.

Wsparciem nauczycieli w zaopatrywanie się w artykuły żywnościowe okazały się dary Organizacji Narodów Zjednoczonych ds. Pomocy i Odbudowy (UNRRA ${ }^{27}$ ) oraz „kartki żywnościowe”. Pierwsze przydziałowe kartki zostały wprowadzone z chwilą otwarcia w czerwcu 1945 r. dużego sklepu artykułów żywnościowych „Mazur” w Olsz-

${ }^{23}$ OBN, zespół; Zbiory Specjalne, sygn. R - 158/X/1, Wspomnienia..., k. 123.

${ }^{24}$ R. Tomkiewicz, Życie codzienne mieszkańców powojennego Olsztyna 1945-1956, Olsztyn 2003, s. 55 .

${ }^{25}$ OBN, zespół: Zbiory Specjalne, sygn. R - 10, Augustyn Klimek..., k. 7.

${ }^{26}$ OBN, zespół: Zbiory Specjalne, sygn. R - 807, Antoni Bąk, Moje życie i praca na Warmii i Mazurach/40-lecie, k. 23.

${ }^{27}$ Organizacja Narodów Zjednoczonych do Spraw Pomocy i Odbudowy (United Nations Relief and Rehabilitations Administration - UNRRA). UNRRA została powołana w 1943 r. w Waszyngtonie z inicjatywy USA, Wielkiej Brytanii, ZSRR, Chin. Układ podpisało 48 państw. Celem organizacji była pomoc krajom alianckim najbardziej dotkniętym wojną, w tym i Polsce. Pomoc obejmowała dostarczanie produktów pierwszej potrzeby, tj. żywności, leków i odzieży. W 1947 r. UNRRA została rozwiązana, a jej agendy przejęły: Międzynarodowy Fundusz Narodów Zjednoczonych Pomocy Dzieciom i Urząd Wysokiego Komisarza Narodów Zjednoczonych do Spraw Uchodźców. 
tynie ${ }^{28}$. Dla wielu nauczycieli przydziały kartkowe były jedyną podstawą ich powojennej egzystencji. Szczególnie trudna sytuacja żywieniowa wystąpiła zimą 1945/46 r. ${ }^{29}$ Sroga zima spowodowała podwyżkę cen żywności ze względu na niedobory artykułów. Niestety pojawiały się też problemy z realizacją przydziałów kartkowych, zwłaszcza u nauczycieli pracujących w małych miejscowościach. Głównym powodem okazały się trudności komunikacyjne. Trzeba było pokonywać spore odległości, aby udać się do miasta powiatowego w celu wykupienia artykułów żywnościowych, co egzemplifikuje wspomnienie nauczyciela Józefa Ostrowskiego ze szkoły w Kipowie w powiecie ostródzkim: Początkowo warunki nauczyciela byty trudne. Chleba we wsi nie byto. Po chleb trzeba byto jechać do Lubawy albo Ostródy, a lokomocji prócz rowera żadnej. Podobnie było z mięsem i tluszczem. Gdy się coś podobnego zdobyto, trzeba byto drogo placić30. Ten przykład wskazuje, że w rytm codziennego życia nauczycieli wpisały się możliwości dokonywania zakupów u przypadkowych sprzedawców, ale po cenach znacznie wyższych oraz zaopatrzenie na rynku zamiennym. Dopiero w kwietniu 1946 r. Ministerstwo Aprowizacji i Handlu wprowadziło fundusz aprowizacyjny dla nauczycieli, którzy za niezrealizowane przydziały kartkowe otrzymywali rekompensatę $\mathrm{w}$ gotówce ${ }^{31}$. Jednak takie rozwiązanie nie sprawdzało się zwłaszcza u nauczycieli zatrudnionych na wsi, gdyż tam za pieniadze nic kupić nie byto można [...]. Natomiast wszystko można byto kupić za $z b o z ̇ e$, mięso i ttuszcz $z^{32}$. Warto dodać, że wypłatą rekompensat za niezrealizowane przydziały kartkowe zajmowały się ogniwa związkowe ZNP, które w niektórych miejscowościach były jeszcze w stadium organizacji, co również pogarszało nieciekawą sytuację aprowizacyjną nauczycieli.

Oprócz braków artykułów żywnościowych do stałych codziennych bolączek nauczycieli zaliczyć też trzeba braki w artykuły odzieżowe. Nauczycielka z Warszawy przyjechała: do Olsztyna prawie nago i boso, dostownie bez niczego. Kiedy musiatam oddać do szewca moje jedyne pantofle, siedziałam u niego, trzymajac nogi na gazecie i dopingujac, aby szybko robil, bo musiałam pędzić do szkoty $y^{33}$. Na kłopoty zaopatrzeniowe w odzież utyskuje też nauczycielka z Łankiejm w powiecie kętrzyńskim: Ja, osobiście największy brak odczuwatam w ubraniu, którego w sprzedaży nie byto ${ }^{34}$. Inna nauczycielka mająca na utrzymaniu rodzinę, tak opisuje zdarzenie, które wiosną 1946 r. pomogło jej uzyskać obuwie dla własnego dziecka: na strychu swego mieszkania znalazłam kilka par różnych rozmiarów drewniaków całkiem dobrych, prawie nowych, uszczęśliwiona obdzielitam

${ }^{28}$ OBN, zespół: Zbiory Specjalne, sygn. R - 27, Teofil Ruczyński, Lech, [Wspomnienia z lat 1945-1957], k. 3 .

29 S. Achremczyk, Historia Warmii i Mazur. Tom 2. 1772-2010, Olsztyn 2011, s. 1107.

${ }^{30}$ OBN, zespół: Zbiory Specjalne, sygn. R - 158/X/1, Wspomnienia..., k. 156.

31 „Głos Nauczycielski” 1946, nr 11 - 12, s. 178 [bez autora i tytułu].

32 OBN, zespół: Zbiory Specjalne, sygn. R - 158/X/1, Wspomnienia ..., k. 99.

33 OBN, zespół: Zbiory Specjalne, sygn. R - 641/4, I. Palińska, Moja pierwsza praca na Warmii, k. 10-11. Praca zgłoszona na nauczycielski konkurs literacki pt. Wspomnienia nauczycieli zorganizowany w 1980 roku przez Kuratorium Oświaty i Wychowania oraz Związek Nauczycielstwa Polskiego w Olsztynie.

${ }^{34}$ OBN, zespół: Zbiory Specjalne, sygn. R - 158/X/1, Wspomnienia ..., k. 77. 
nimi najuboższe dzieci, pozostawiając 1 parę swemu bosemu synkowi, który też do szkoty chodzit ${ }^{35}$.

Nie da się ukryć, że w tej powojennej codzienności poważnym strapieniem był brak pieniędzy. Chociaż wciąż istniały kłopoty zaopatrzeniowe, to i tak trzeba było mieć pieniądze, m.in. na wykupienie produktów na karty żywnościowe ${ }^{36}$, czy obiadów w stołówce nauczycielskiej ${ }^{37}$. Pierwsze pobory uregulowane zarządzeniem Ministra Oświaty z dnia 19 września 1945 r. $^{38}$ do nauczycieli szkół powszechnych w Okręgu Mazurskim trafiły dopiero w ostatnim kwartale br. Wysokość wynagrodzenia uzależniona była od przynależności do grupy uposażeniowej. Biuro Ziem Odzyskanych informowało, że od października 1945 r. nauczyciele szkół powszechnych będą pobierać uposażenie według X, IX, VIII, VII, VI, lub V grupy uposażeniowej. Przy ustaleniu wysługi lat do wymiaru uposażenia zaliczyć należy lata służby i kwalifikacje ${ }^{39}$.

Zgodnie z nowymi stawkami wynagrodzenie nauczycieli szkół powszechnych wraz z dodatkami wojennym i nauczycielskim powinno kształtować się od 975 zł w X grupie uposażeniowej do 1750 zł w najwyższej grupie uposażenia. Jednak jak wynika ze wspomnień nauczyciela zatrudnionego w październiku 1945 r. w powiecie olsztyńskim, jego pierwsza pensja nauczycielska wynosiła znacznie poniżej stawek ustalonych przez BZO: otrzymałem nominację na kierownika szkoły powszechnej w Pluskach z wynagrodzeniem 370, - złotych miesięcznie; to była najwyższa stawka, jaka dysponowat wówczas Inspektorat/ pierwsza stara waluta ${ }^{40}$. Podobne wynagrodzenie otrzymała nauczycielka ze szkoły w Dźwierzutach w powiecie piskim: Pierwsze pobory dostaliśmy na jesieni $w$ X lub XI. Podstawa wyżwienia byt chleb razowy i ziemniaki. O mleko było trudno, a thuszcz drogo kosztowat. Za pierwszy $\mathrm{kg}$ smalcu po wojnie zapłaciłam $400 \mathrm{zt-prawie} \mathrm{miesięcz-}$ na pensję $e^{41}$.

W styczniu 1946 r. do dotychczasowych składników wynagrodzenia nauczycielskiego wprowadzono na Ziemiach Północnych i Zachodnich dodatek zachodni (lokalny). Dodatek lokalny za pracę na trudnych terenach, do jakich również zaliczono Okręg Mazurski, przyznano nauczycielom w wysokości $50 \%$ uposażenia zasadniczego ${ }^{42}$. Pomimo

35 Ibidem, k. 71.

${ }^{36}$ Ibidem, k. 99.

${ }^{37}$ OBN, zespół: Zbiory Specjalne, sygn. R - 322. Jadwiga Lindner, Z myślą o Warmii i Mazurach, k. 10. Dodatek stołówkowy wprowadzono 1 sierpnia 1945 roku w wysokości 600 złotych.

38 Zarządzenie Ministerstwa Oświaty z dnia 19 września 1945 (Nr IP-4784/45N) wydane w porozumieniu z Ministrem Skarbu, w sprawie wynagrodzenia nauczycieli publicznych szkół powszechnych (szkół ćwiczeń, szkół specjalnych), szkół średnich ogólnokształcących i zakładów kształcenia nauczycieli oraz szkół zawodowych, z tytułu nauczania lub zajęć w godzinach nadliczbowych.

${ }^{39}$ Archiwum Akt Nowych w Warszawie (AAN), zespół: Ministerstwo Oświaty, sygn. 1235, Uposażenie nauczycieli na Ziemiach Odzyskanych, k. 162.

${ }^{40}$ OBN, zespół: Zbiory Specjalne, sygn. R - 323, Czesław Boguski ..., k. 2.

${ }^{41}$ OBN, zespół: Zbiory Specjalne, sygn. R - 158/X/1, Wspomnienia..., k. 190.

${ }^{42}$ Dekret z dnia 12 czerwca 1946 roku o zmianie Rozporządzenia Prezydenta Rzeczypospolitej z dnia 28 października 1933 o uposażeniu funkcjonariuszów państwowych w: Przepisy służbowe nauczycieli. Zbiór obowiązujących przepisów prawnych w zakresie pragmatyki, odpowiedzialności stużbowej i uposażeń nauczycieli, wraz z orzecznictwem Najw. Trybunału Adm, zebrali i opracowali: W. Wilanowski, J. Wójcik, J. Buczkowski, Warszawa 1946, s. 425. 
dodatkowych przywilejów finansowych, w Okręgu Mazurskim występowała skrajnie trudna sytuacja materialna nauczycieli. Niektóre inspektoraty szkolne, będąc w stadium organizacji, nie miały możliwości wypłacenie obowiązujących nauczycieli poborów. Taka sytuacja w 1946 r. miała miejsce m.in. w powiecie mrągowskim, co potwierdza Maria Zagórska ze szkoły w Pieckach: Ja żłam w bardzo cięzkich warunkach, bo $w$ pierwszych miesiacach pensji nie otrzymywałam, gdyż Inspektorat Szkolny dopiero zaczą istnieć i nie byto pieniędzy. [...] Potem otrzymywałam już pobory, poczatkowo bardzo skromne, a następnie większe. [...] najgorzej było ze stonina, mięsem itp. Za $1 \mathrm{~kg}$ słoniny przywiezionej z Polski dawaliśmy $1 \mathrm{~m}$ żyta ${ }^{43}$.

Kolejna znaczna podwyżka płac nauczycielskich nastąpiła w maju 1946 r. i kształtowała się od 1370 zł w grupie X do 2030 zł w grupie V. Największy, ośmiokrotny przyrost wynagrodzenia w stosunku do roku ubiegłego nastąpił w ostatniej grupie uposażeniowej, czyli obejmującej znaczny odsetek nauczycieli szkolnictwa powszechnego.

Niewiele jest wspomnień opisujących życie codzienne nauczycieli w ich własnych gospodarstwach domowych. Niektórzy pamiętnikarze - jak nauczyciel z powiatu mrągowskiego ze szkoły w Urżankach - relacjonują, że podstawowymi produktami żywieniowymi: byty ziemniaki i fasola oraz kasza z prosa, która otrzymywano z przydziałów ${ }^{44}$. Przydziały po części rozwiązywały trudną sytuację żywieniową, na co wskazuje przykład nauczycielki z powiatu suskiego: Dostałam z gminy na zasiew $1 \mathrm{~m}$ jęczmienia. $1 / 2 \mathrm{~m}$ zasiałam, a z 1/2 m gospodarz zrobit mi kaszę. I tak, dzień $w$ dzień na śniadanie, obiad $i$ kolację miałam krupnik zasiniony mlekiem (krowa byta na ocieleniu). Od czasu do czasu dostawałam na kartki prowiant $w$ Suszu. Dojazd byt trudny i od stacji $7 \mathrm{~km}$ trzeba było wszystko na plecach przydźwigać - prowiant, zeszyty itd. Koni we wsi prawie nie byto ${ }^{45}$. O innych sposobach radzenia sobie w zmaganiach $\mathrm{z}$ codziennością wspomina nauczyciel z Biesala w powiecie ostródzkim: Łapałem ryby, założyłem pasiekę z roju znalezionego $w$ lesie. $Z$ chwila nabycia krowy i prosiaka minimum egzystencji było zapewnione. Lasy dostarczały grzybów i jagód ${ }^{46}$.

Trudno jest też ustalić, jak nauczyciele gospodarowali własnym budżetem. Jako przykład przytaczam fragment wspomnień nauczyciela ze szkoły w powiecie olsztyńskim, który na początku 1946 r.: jako kierownik szkoty otrzymywałem 1000 zł na stara walutę. Za pobory mogłem kupić niecałe $2 \mathrm{~kg}$ słoniny. 550 zł kg, 1 litr oleju $350 \mathrm{zt}$. Nie było nawet ziemniaków, a na utrzymaniu miałem 7 osób. W tym 70-cio letnia ciotkę zmartej żony $i$ dwoje matych dzieci kuzynki. Gmina miała dostarczyć nauczycielom make na chleb, lecz nigdy tego nie czyniła, brakowało opału, nie było ubrania i butów. Za przydziat materiału, który po miesiacu rozleciat się, musiałem zapłacić $700 z z^{47}$. Na inne trudności w prowadzeniu gospodarstwa domowego wskazuje nauczyciel Władysław Stefanowicz ze szkoły w pruskim powiecie iławeckim: ciężki byt i stan majątkowy nauczy-

\footnotetext{
${ }^{43}$ OBN, zespół: Zbiory Specjalne, sygn. R - 158/X/1, Wspomnienia ..., k. 101.

44 Ibidem, k. 102.

45 Ibidem, k. 55.

46 Ibidem, k. 138.

${ }^{47}$ OBN, zespół: Zbiory Specjalne, sygn. R - 13, Wspomnienia z pierwszych lat pracy powojennej, k. 1.
} 
cieli. Pensja była zupetnie mała i to wyptacana nieregularnie. Trzeba było dorabiać na stronie, aby jakoś zwiazać koniec z końcem. Remont mieszkania nauczyciela, jak: piec, okno, drzwi, podłogi itd. musiał nauczyciel sam na własna rękę jakoś prowadzić. Przydziału opatu też nie było, wszystko to spoczywało na barkach nauczyciela ${ }^{48}$.

Nauczyciele w Okręgu Mazurskim prawie w każdej sprawie, jak sami podkreślają, byli zdani na łaskę losu ${ }^{49}$. Zdarzały się przypadki, gdzie o ich warunki pracy i warunki socjalno-bytowe zatroszczyły się władze oświatowe i lokalne. Takie wyróżnienie spotkało m.in. Władysława Pelczarskiego ze szkoły w Ornowie, powiat ostródzki: Początkowo bytem na utrzymaniu ówczesnego soltysa, który zobowiązat się w Inspektoracie Szkolnym dać wyżywienie nauczycielowi. Na to stać go było, gdyż w jego rękach spoczywało też całe życie gospodarcze wsi. W IX 1945 otrzymatem pierwsze pobory. Od tego czasu przeszedłem na własne utrzymanie. Miałem trudności w zaopatrywaniu się $w$ chleb i thuszcz. Pewna pomoc otrzymałem od jednostki radzieckiej ${ }^{50}$.

Z pomocą nauczycielom przychodzili najczęściej rodzice uczniów. Wspierali nauczycieli na różne sposoby, poczynając od pomocy przy organizacji szkoły aż po przydzielenie mieszkania, utrzymanie, wyżywienie (Tylko rodzice uczniów przynosili ziemniaki, kapustę, masło itp., abym mogła przeżyć te najgorsze miesiace $\left.{ }^{51}\right)$, czy wsparcie finansowe. Dochód pochodzący z funduszów komitetów rodzicielskich był uznawany za trzecią, obok płac w gotówce i świadczeń w naturze, nieoficjalną formę uposażenia nauczycielstwa. Nauczyciele w Okręgu Mazurskim korzystali z tej formy wsparcia, co dokumentuje wypowiedź jednej z nauczycielek szkoły w Olsztynie: Nauczyciel jest ciagle w sytuacji upokarzajacej [...] korzysta z wielu darowizn, ale czas jest wojenny, przejściowy [...] Opłata rodziców to nie jatmużna - to jest zrozumienie obecnej sytuacji, tj. normalne wynagrodzenie ${ }^{52}$.

W początkowym okresie sytuacja osobista nauczycieli była zróżnicowana, spowodowana zwłaszcza poczuciem tymczasowości. Niektórzy przybywali do Okręgu Mazurskiego samotnie, aby po tzw. etapie zagospodarowania się sprowadzić rodzinę. Inni, zwłaszcza nauczyciele napływowi, od razu sprowadzali się z rodziną, jak to miało miejsce w przypadku Eugenii Muszyn. Przybyła ona wraz z rodziną 1 maja 1946 r. z Wileńszczyzny i podjęła pracę $\mathrm{w}$ szkole $\mathrm{w}$ powiecie kętrzyńskim ${ }^{53}$. Ludność naptywowa przywiozła ze soba zapasy żywności, nasiona $i$ inwentarz żywy ${ }^{54}$. Z analizy przekazów pamietnikarskich wynika, że w zdecydowanie lepszej sytuacji materialnej znaleźli się nauczyciele, którzy przybyli do Okręgu Mazurskiego z Kresów Wschodnich, gdyż opuszczając swoje dotychczasowe miejsce zamieszkania zabierali ze sobą m.in. zapasy żyw-

${ }^{48}$ OBN, zespół: Zbiory Specjalne, sygn. R - 158/X/1, Wspomnienia..., k. 15.

49 Ibidem, k. 179.

50 Ibidem, k. 136

51 Ibidem, k. 101

52 Zbiory archiwalne Szkoły Podstawowej nr 2 im. Jarosława Dąbrowskiego w Olsztynie, Księga Protokołów Rady Pedagogicznej 1946 - 1949, sygn. 7/2, Protokół nr 2 z dnia 28 lutego 1946 roku.

53 OBN, zespół: Zbiory Specjalne, sygn. R - 158/X/1, Wspomnienia..., k. 71.

${ }^{54}$ OBN, zespół: Zbiory Specjalne, sygn. $\mathrm{R}$ - 13, Wspomnienia z pierwszych lat pracy powojennej, k. 1. 
ności, pościel, ubrania, garnki i inwentarz żywy, co znacznie ułatwiało im start w trudnych latach powojennych ${ }^{55}$.

Warto dodać, że sytuację materialną nauczycieli posiadających na utrzymaniu rodzinę „ratował” dodatek ekonomiczny, czyli rodzinny. W październiku 1945 r. dodatek rodzinny wynosił po 100 zł na każdego członka rodziny ${ }^{56}$, a w maju 1946 r. podwyższono go do kwoty $200 \mathrm{z}^{57}$. Jednak te dodatkowe środki nie wystarczały chociażby na opłacenie jakiejkolwiek opieki nad małoletnimi dziećmi nauczycieli. Dlatego też zdarzały się przypadki, gdzie nauczycielki zabierały własne dzieci do pracy. Fakt ten potwierdza jeden z ówczesnych uczniów: wychowawczynią była Pani Stawecka, wdowa, której mąż zginąt na wojnie. Często zabierała do szkoły swoja śliczna córeczkę Ewę $e^{58}$.

Sytuacja mieszkaniowa nauczycieli szkół powszechnych w Okręgu Mazurskim, zwłaszcza w 1945 r. nie była najgorsza. Nauczyciele jedni z pierwszych mieszkańców mieli jeszcze możliwość wyboru nie tylko miejsca zamieszkania, ale i lokalu mieszkalnego. Przeważnie decydowali się na puste mieszkania zlokalizowane niedaleko miejsca pracy, w pobliżu szlaków komunikacyjnych, przeważnie w miastach. Na przykład w Kętrzynie, jak zauważa nauczyciel, w okresie lipiec-sierpień 1945 r.: mieszkań było dużo, więc można było sobie wybrac ${ }^{59}$. Jednak nie wszyscy zgłaszający się do pracy nauczycieli mogli zarówno pracować, jak i mieszkać tylko w miastach regionu Warmii i Mazur.

Najlepszą alternatywą dla ówczesnych nauczycieli było zamieszkiwanie w budynku szkolnym lub w lokalu mieszkalnym w pobliżu placówki szkolnej. Niestety takie możliwości przytrafiały się nielicznym nauczycielom, stąd większość narzekała na lokalizację i warunki mieszkaniowe, które pogarszały się wraz z napływem ludności do Okręgu Mazurskiego. Nauczycielka Rufina Tatarczuk, która przybyła z Wileńszczyzny po zatrudnieniu w charakterze nauczyciela w szkole w Zielonce w powiecie szczycieńskim, musiała zamieszkać u gospodarza, gdyż: brak było mieszkania dla nauczyciela $w$ szkole ${ }^{60}$. Początkowo w podobnej sytuacji w listopadzie 1945 r. znalazła się nauczycielka ze szkoły w Miłomłynie: mieszkania nie mam [...] pan sekretarz Gminy mówi mi żebym czasowo zamieszkała w jednym z pokoi jego mieszkania. [...] Od paru dni chodze po Miłomtynie w poszukiwaniu mieszkania. Bezskutecznie, bo prawie wszystkie mieszkania sa zdewastowane i ograbione... Na drzwiach lepszych mieszkań są kartki z napisem: „Zajęte”. Więc bezcelowo bytoby mnie wprowadzić się tu przemoca, bo nie wiem przez kogo i po co zajęte? Pani sekretarzowa wymawia mnie mieszkanie, bo tam ma suszyć bielizne wyprana przed świętami. Więc jej mąż, ratując przykra sytuację, proponuje mi duży budynek

55 Ibidem, k. 143, 155.

${ }^{56}$ AZG ZNP, zespół: Wydział Organizacyjny, sygn. 1436, Ewolucja uposażeń nauczycielskich. Confer: Przepisy..., s. 403, 421.

${ }^{57}$ AZG ZNP, zespół: Wydział Organizacyjny, sygn. 1436, Ewolucja uposażeń nauczycielskich, bez pag.

${ }_{58}$ Zbiory archiwalne Szkoły Podstawowej nr $1 \mathrm{im}$. Ryszarda Knosały w Olsztynie, Kronika szkoły, Wspomnienie Andrzeja Poduszko - absolwenta $1953 \mathrm{r}$.

${ }^{59}$ OBN, zespół: Zbiory Specjalne, sygn. R - 158/X/1, Wspomnienia..., k. 83.

${ }^{60}$ Ibidem, k. 180. 
Urzędu Poczty, jeszcze nie zajęty. Tam moga być i klasy i mieszkania nauczycielki. Zgadzam się $e^{61}$.

Sytuacja mieszkaniowa nauczycieli na wsi uległa znacznej poprawie z chwilą wejścia w życie instrukcji nakładającej na gminy „obowiązek [...] dostarczania mieszkań dla nauczycieli i w ogóle pokrywania wydatków rzeczowych"62. W miarę swoich możliwości gminy nie uchylały się od tego obowiązku, co udowadnia nauczycielka ze szkoły w Rudzienicach: przyjechałam 1 marca 1946 r. z rodzina, rzeczami i inwentarzem (krowa, świnia, owca, 6 kur). Na wstępie ogarnęto mnie przerażenie. W szkole nikt i nic nie zrobit. Mnie zaś z rodzina soltys skierowat do mieszkania przy szkole bez okien, drzwi i z rozwalonymi piecami. I dopiero po kilkugodzinnym poszukiwaniu znalazłam mieszkanie u jednego z gospodarzy, który przenióst się w okolice Ostródy. Załatwiłam więc sprawe przydzielenia mi tego gospodarstwa i mieszkam tu do dnia dzisiejszego ${ }^{63}$. Inne wspomnienia dotykają warunków mieszkaniowych: Moje mieszkanie prywatne $w$ tym czasie składało się z jednej izby u gospodarza wsi. Mieszkałam tu razem z trójka dzieci w wieku szkolnym. W izbie tej mieściło się tylko jedno łóżko, stół $i$ dwa krzesła. Jedno z moich dzieci było ciężko chore [...] mimo dużej odległości $/ 15 \mathrm{~km} /$ od szpitala i lekarza musiałam co 2-3 miesiace wozić dziecko do szpitala, gdzie na zmiane zakładano lub zdejmowano gips. Do szkoły nosiłam je na plecach, potem woziłam na wózku zrobionym przez dzieci szkolne ${ }^{64}$. W większości pamiętnikarze narzekają na trudne warunki mieszkaniowe, zwłaszcza na niski standard mieszkań lub izb mieszkalnych, potrzebę gruntownego remontu i przynajmniej niezbędnego wyposażenie, gdyż - jak mieszkanie nauczycielki w powiecie kętrzyńskim - było zupetnie wyszabrowane ${ }^{65}$.

Chociaż w 1946 r. pojawiły się trudności mieszkaniowe ze względu na wzmożony ruch osadniczy, to cztery miesiące później Ministerstwo Oświaty zapewniało, że „są mieszkania zabezpieczone dla nauczycieli, są zwykłe budynki gospodarcze i rola na wsi przeznaczona dla nauczycieli”66 na Ziemiach Odzyskanych, w tym i w Okręgu Mazurskim.

O wyborze miejsca zamieszkania decydował nie tylko fakt istnienia mieszkań dla nauczycieli, ale przede wszystkim względy bezpieczeństwa ${ }^{67}$ oraz odległość od szlaków komunikacyjnych. W ówczesnych czasach powszechnym środkiem komunikacji były konie $^{68}$ nie tylko na wsiach, ale i w miastach. Nauczyciele, podobnie jak inni mieszkańcy Okręgu Mazurskiego przemieszczali się pociągami towarowymi, a najczęściej na własnych

${ }^{61}$ AZG ZNP, zespół: Biuro Historii, sygn. 899, Wanda Gumienna..., k. 1-2.

${ }^{62}$ Tymczasowe instrukcje o zakresie i sposobie działania wójtów w Okręgu Mazurskim oraz sołtysów i sołtysów miejskich z dnia 1 listopada 1945 r. Podano za: Starostwo Powiatowe w Olsztynie 1945-1950. Wybór dokumentów, wybrał, wstępem i komentarzem opatrzył Robert Syrwid, Olsztyn 2009, s. 67.

${ }^{63}$ OBN, zespół: Zbiory Specjalne, sygn. R - 158/X/1, Wspomnienia ..., k. 53.

${ }^{64}$ AZG ZNP, zespół: Biuro Historii, sygn. 899, Kosowa Nadzieja..., k.2.

${ }^{65}$ OBN, zespół: Zbiory Specjalne, sygn. R - 158/X/1, Wspomnienia ..., k. 78.

${ }^{66}$ APO, zespół: KOS, sygn. 495/6, Kierowanie nauczycieli na tereny Z.O., k. 10.

${ }^{67}$ Ministerstwo Oświaty, mając na uwadze stan bezpieczeństwa osobistego nauczycieli oraz warunki spokojnej pracy w szkole, rozpatrywało również możliwość zezwolenie nauczycielstwu Ziem Odzyskanych na zaopatrzenie się i noszenie broni krótkiej. AZG ZNP, zespół: Wydział Ekonomiczno-Prawny, sygn. 12, Stan bezpieczeństwa na ziemiach odzyskanych. Warszawa, dn. 19 lutego 1946 roku, k. 2.

${ }^{68}$ OBN, zespół: Zbiory Specjalne, sygn. R - 312, Giżycko. Wspomnienia z lat 1945, k. 3. 
nogach, rzadziej rowerem. Wyrazy uznania należą się nauczycielowi Emilowi Górnemu, który pieszo pokonał prawie dwustukilometrową trasę z Przasnysza do Górowa Iławieckiego, aby tam otworzyć szkołę ${ }^{69}$. Również nauczyciele w Olsztynie o własnych nogach przenosili sprzęt szkolnych, gdyż Nie było żadnego transportu, trudno było o furmankę, nie mówią już o samochodzie ${ }^{70}$. Jak wynika z relacji nauczycieli marzeniem wówczas było posiadanie roweru, którego i tak nie było za co kupić, ponieważ pierwsze było ubranie a nie rower ${ }^{71}$. Jednak niektórzy z nauczycieli mogli poszczycić się dojazdem do miejsca pracy właśnie rowerem, co podkreśla nauczycielka z powiatu ostródzkiego: zajęcia w szkole prowadzily dwie młode panny nauczycielki /bardzo krótko/, które dojeżdzały rowerem z odległości $15 \mathrm{~km}$ od Ostródy $y^{72}$.

Czas wolny, jaki pozostawał po pracy i wypełnieniu obowiązków domowych, nauczyciele przeznaczali na czynności o charakterze praktycznym (porządkowanie i urządzanie mieszkań), samokształcenie, prace dodatkowe, spontaniczne nieformalne spotkania towarzyskie.

Wolnym dniem od pracy zawodowej była niedziela. Dla niektórych nauczycieli jej rytm wyznaczało uczestnictwo wraz z uczniami klas pierwszych w Mszy Świętej ${ }^{73}$. To był obyczaj jeszcze z okresu międzywojennego, który w niedalekiej przyszłości „miał planowo zaniknąć"74. Natomiast w ramach samokształcenia, oprócz nauki własnej, nauczyciele rozwijali własną twórczość, w amatorskim ruchu kulturalnym, na co wskazują dane: w grudniu 1945 roku istniało na terenie Okręu Mazurskiego 7 zespołów teatralnych, w których działali wytacznie nauczyciele ${ }^{75}$.

Codzienne życie nauczycieli urozmaicane było skromnymi formami spędzania czasu wolnego. Najpopularniejszą z nich były spotkania towarzyskie. W powojennym czasie najczęściej odbywały się one w stołówkach, co tak opisuje Jadwiga Lindner: Do stołówki przy ul. W. Kętrzyńskiego, tam gdzie mieściło się pierwsze Kuratorium Okręgu Szkolnego Mazurskiego, wędrowało się pieszo. Tu spotykaliśmy się z całym ówczesnym nielicznym gronem nauczycieli szkót olsztyńskich $i$ nawiązywaliśmy pierwsze międzyszkolne kontakty $^{76}$. Tak było w miastach, natomiast w małych miejscowościach spotkania towarzyskie nauczycieli były ograniczone. Najczęściej odbywały się przy organizowaniu różnych form dokształcania: W połowie czerwca [1945 r.] odbyła się w Olsztynie pierwsza konferencja nauczycielska z miasta i powiatu z udziałem 17 nauczycieli. Z Olsztyna było 2 nauczycieli, którzy uczyli razem około 30 dzieci. Z Barczewa był 1. Zapoznałem się na

${ }^{69}$ OBN, zespół: Zbiory Specjalne, sygn. R - 158/X/1, Wspomnienia ..., k. 24.

${ }^{70}$ Zbiory archiwalne Szkoły Podstawowej nr 1 im. Ryszarda Knosały w Olsztynie, Kronika szkoły, Ze wspomnień nauczyciela Hieronima Borkowskiego.

71 OBN, zespół: Zbiory Specjalne, sygn. R - 158/X/1, Wspomnienia..., k. 52.

72 AZG ZNP, zespół: Biuro Historii, sygn. 899, Kosowa Nadzieja..., k. 1.

${ }^{73}$ B. Berlińska, R. Karpińska, 60-lecie Szkoły Podstawowej nr 2 imienia Jarosława Dąbrowskiego w Olsztynie, Olsztyn 2005, s. 52.

${ }^{74}$ T. Czekalski, Dewaluacja obyczaju, w: Obyczaje w Polsce. Od średniowiecza do czasów nowożytnych, red. A. Chwalba, Warszawa 2008, s. 346.

75 AZG ZNP, zespół: Biuro Historii, sygn.1023, Organizacja..., k. 39.

${ }^{76}$ OBN, zespół: Zbiory Specjalne, sygn. R - 322, Jadwiga Lindner..., k. 10. 
tej konferencji z kolegami z sąsiednich Gronit, Naterek i Dorotowa, których później zwiedzałem celem zapoznania się z lepsza metoda nauczania ${ }^{77}$. Część towarzyska kursów była pewnego rodzaju obyczajem. Inni nauczyciele w wolnych chwilach spotykali się, aby: [...] snuliśmy wspomnienia z przeżyć okupacyjnych ${ }^{78}$. Na przykład nauczyciel szkoły w Czerniku - były uczeń gimnazjum polskiego w Kwidzynie - w rozmowie z A. Klimkiem wspominał o swoim dyrektorze dr. Władysławie Gębiku ${ }^{79}$. Na pierwszej gwiazdce bożonarodzeniowej w szkole $\mathrm{w}$ Tomaszkowie pojawili się Edward Turowski ${ }^{80}$ i Jan Boenigk $^{81}$ - nauczyciele i działacze oświatowi w Prusach Wschodnich, którzy: Przypominali zgromadzonym rodzicom i dzieciom, że [...] powinni wszyscy z powrotem tak mówić, jak mówili nasi przodkowie na naszej Warmii, jęzkkiem polskim. Dalej opowiadali swoje przeżycia w obozach koncentracyjnych $i$ na wojnie, $i$ że zamierzaja teraz pracować dla ludu warmińskiego ${ }^{82}$.

Niektórzy nauczyciele czas wolny przeznaczali na organizowanie zajęć pozalekcyjnych dzieciom, co potwierdza nauczycielka ze szkoły w Likuzach: Uczyłam moje dziewczynki haftować i gotować. Ciasteczka, z braku piecyka i kuchni, piektyśmy u mnie $w$ domu. Zjadałyśmy je potem na wspólnych wypadach do lasu ${ }^{83}$. Można przypuszczać, że spotkaniom towarzyskim sprzyjał okres wakacji. Niestety pierwsze wakacje w Okręgu Mazurskim były bardzo krótkie. Np. w szkole powszechnej w Olsztynie pierwszy rok szkolny zakończył się 25 lipca 1945 r., a kolejny rozpoczął 3 września 1945 r. Stąd większość nauczycieli czas wakacji poświęciła na remonty zorganizowanych już szkół po-

77 OBN, zespół: Zbiory Specjalne, sygn. R-465, P. Turowski..., k. 93-94.

78 OBN, zespół: Zbiory Specjalne, sygn. R - 10, Augustyn Klimek..., k. 10.

79 Władysław Gębik (1900-1986) był organizatorem i dyrektorem otwartego 10 listopada 1937 r. pierwszego w Prusach Wschodnich polskiego gimnazjum w Kwidzynie. Cel działania gimnazjum sprowadzał się do wychowania kadry kierowniczej ruchu polskiego w Niemczech. 25 sierpnia 1939 r. uczniów i nauczycieli gimnazjum aresztowano i wywieziono do obozu koncentracyjnego. B. Koziełło-Poklewski, W. Wrzesiński, Szkolnictwo polskie na Warmii, Mazurach i Powiślu w latach 1919-1939, Olsztyn 1980, s. 225, 244. Po wojnie objął stanowisko naczelnika Wydziału Szkół Średnich Kuratorium Mazurskiego Okręgu Szkolnego w Olsztynie. W marcu 1946 r. założył Oddział Towarzystwa Teatrów i Muzyki Ludowej. W latach 1948-1950 kierownik Inspektoratu Kulturalno-Oświatowego Spółdzielni Wydawniczej „Czytelnik” w Olsztynie, a także prezes Zarządu Wojewódzkiego Towarzystwa Wiedzy Powszechnej. W latach 1950-1957 sprawował funkcję kierownika olsztyńskiej delegatury Państwowego Instytutu Sztuki. Zajmował się zbieraniem rodzimego folkloru. Był działaczem społeczno-kulturalnym. S. Achremczyk, Historia Warmii i Mazur, t. 2: 1772-2010, Olsztyn 2011, s. 1223-1224, 1231-1232.

${ }^{80}$ Edward Turowski (1904-1972) - w latach 1929-1935 nauczyciel szkół polskich w Nowej Kaletce i Giławach na terenie Prus Wschodnich. Na skutek represji władz niemieckich pozbawiony prawa nauczania w rejencji olsztyńskiej. W latach 1939-1945 był więźniem w Sachsenhausen oraz służył w niemieckich oddziałach pomocniczych. W grudniu 1945 r. wrócił na rodzimą Warmię i przejął za brata kierownictwo w szkole powszechnej w Tomaszkowie. T. Oracki, Słownik biograficzny Warmii, Mazur i Powiśla XIX i XX wieku (do 1945 roku), Warszawa 1983, s. 316-317.

81 Jan Boenigk (1903-1982) - nauczyciel szkół polskich na Powiślu, działacz społeczny i oświatowy w Prusach Wschodnich. Organizator jedynej szkoły polskiej na Mazurach w Piasutnie. Aresztowany w 1939 r. W roku 1942 wcielony do Wermachtu. W 1945 r. powrócił na rodzimą Warmię. W latach 1946-1950 kierował Warmińskim Uniwersytetem Ludowym w Jurkowym Młynie. T. Filipkowski, Oświata na Warmii i Mazurach w latach 1945-1960, Warszawa 1978, s. 193

82 OBN, zespół: Zbiory Specjalne, sygn. R-465, P. Turowski..., k. 103-104.

${ }^{83}$ OBN, zespół: Zbiory Specjalne, sygn. R-641/4, I. Palińska..., k. 10. 
wszechnych $^{84}$ albo na przygotowania do otwarcia nowych obiektów szkolnych. O rekreacji i turystyce $\mathrm{w}$ życiu nauczycieli możemy mówić dopiero od przerwy wakacyjnej w $1946 r^{85}$

Wśród zagadnień socjalno-bytowych we wspomnieniach nauczycieli pomijany jest problem świadczeń socjalnych, opieki zdrowotnej. Trudno jest też scharakteryzować ubiór nauczycieli (Pamiętam również maleńka nauczycielkę, która nazywaliśmy „Pchełka”. Ubierała się $w$ zielona bluzkę i granatowa spódnice oraz nosiła czerwony krawat $\left.{ }^{86}\right)$.

Oblicza codzienności w powojennej Polsce, w tym i na Warmii i Mazurach były różne. Jednak - jak wspominają nauczyciele - Mimo niewygód $i$ wyrzeczeń nikt nie narzekat, nikt nie pytat, ile nam będa płacić - zapłata byto nam poczucie dobrze spetnionego obowiązu wobec wyzwolonej Ojczyzny ${ }^{87}$.

W tym czasie wszystko nas cieszyło! Naprawdę byliśmy chyba szczéśliwi! Szkoła nasza z każdym dniem stawała się piękniejsza i bogatsza. Niemal codziennie coś do niej przybywało: doniczki na szklanych półeczkach, prawdziwe firanki (nie bibułkowe), obrazki, rysunki dzieci, pomoce naukowe i ksiażki [...] Życie uptywało nam szybko i radośnie. [...] Praca stawała się z każdym dniem łatwiejsza ${ }^{88}$.

Reasumując, życie codzienne nauczycieli szkół powszechnych w Okręgu Mazurskim było urozmaicone, co wynikało ze specyficznych uwarunkowań regionu. Codzienność W świecie powojennej rzeczywistości ulegała nieustannym przeobrażeniom, co spowodowało, że życie codzienne nauczycieli ograniczało się do wszelkich aspektów życia zawodowego, umniejszając sferę życia osobistego i rodzinnego.

Próba ukazania życia codziennego nauczycieli w pierwszych latach powojennych stanowi jedynie zasygnalizowanie niektórych elementów codzienności. Wydaje się zatem, że zmieniająca się rzeczywistość edukacyjna wyznacza oczekiwania i potrzeby podjęcia szerszych badań tej problematyki, z wykorzystaniem różnorodnego materiału źródłowego. Nieodzowne jest też przedstawienie życia codziennego nauczycieli w Polskiej Rzeczypospolitej Ludowej, zwłaszcza w aspekcie sfery ludzkiej psychiki i mentalności, gdyż jak twierdzi M. Bogucka egzystencja w czasie [...] wprowadzania nowego ustroju itd. petna jest elementów dotykających masy ludzi, wplywających na ich bytowanie w sposób bezpośredni i znaczacy ${ }^{89}$.

\footnotetext{
${ }^{84}$ Zbiory archiwalne Szkoły Podstawowej nr 1 im. Ryszarda Knosały w Olsztynie, Kronika szkoły.

${ }^{85}$ W roku 1946 nauczyciele - opiekunowie szkolnych kół sportu i turystyki - z Olsztyna, Ostródy i Giżycka uczestniczyli wraz z harcerzami w obozach turystycznych po Warmii i Mazurach. AZG ZNP, zespół: Biuro Historii, sygn.1023, Organizacja ..., k. 38.

${ }^{86}$ Zbiory archiwalne Szkoły Podstawowej nr $1 \mathrm{im}$. Ryszarda Knosały w Olsztynie, Kronika szkoły, Wspomnienie Andrzeja Poduszko - absolwenta $1953 \mathrm{r}$.

${ }^{87}$ OBN, zespół: Zbiory Specjalne, sygn. R - 10, Augustyn Klimek..., k. 10.

${ }^{88}$ OBN, zespół: Zbiory Specjalne, sygn. R-641/4, I. Palińska..., k. 11-12.

89 M. Bogucka, Życie..., s. 253.
} 


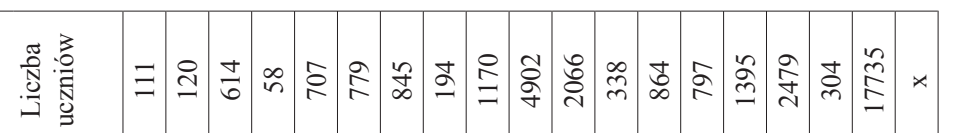

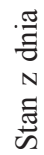

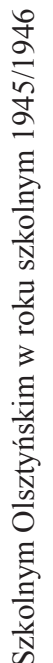

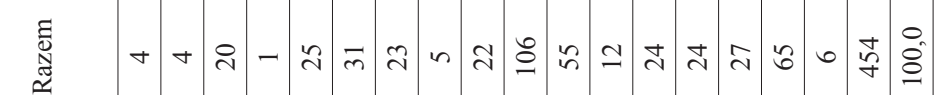

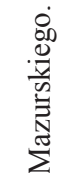

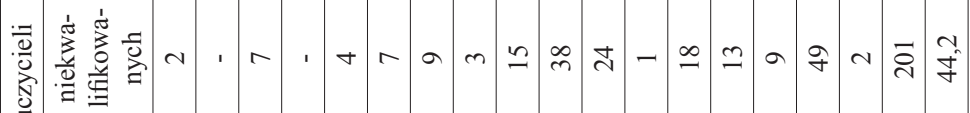

节

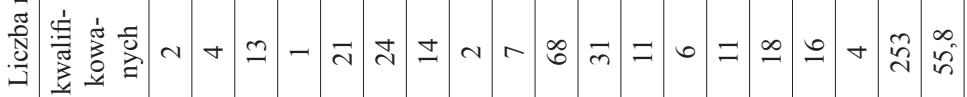

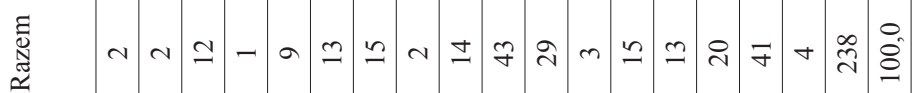

$\frac{\dot{d}}{8}$

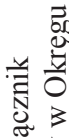

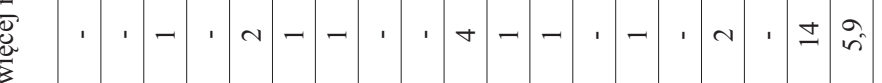

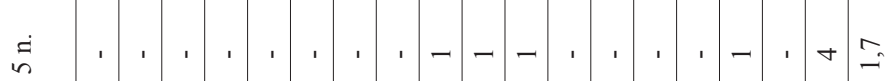

$\frac{\sqrt[0]{\mathrm{N}}}{\mathrm{N}}$

:

츨

$\ddot{0}=$

$\stackrel{\dot{q}}{\stackrel{4}{*}}$

文

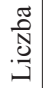

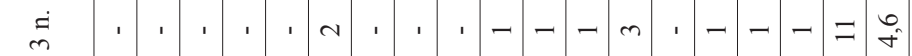

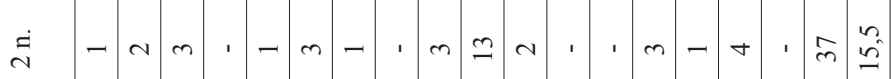

离

需

3

菜

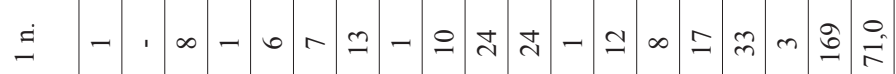

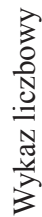

乙

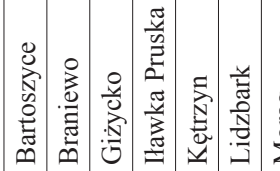

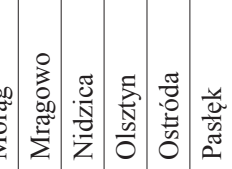

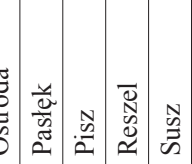

离

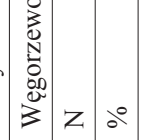

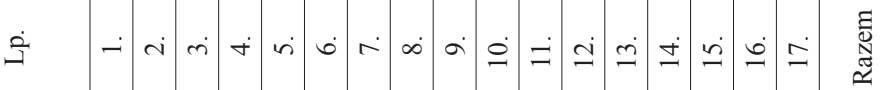

$\stackrel{\stackrel{\sigma}{\sigma}}{\frac{\sigma}{2}}$

हो
क
की
0
0

客

\&

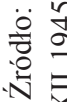

